\title{
Predictors of the Effectiveness and Efficiency of Student Affairs and Services (SAS) among Higher Education Institutions (HEI's)
}

\author{
Flora H. Salandanan', Lerma P. Buenvinida'2, Marcial M. Bandoy ${ }^{3}$ \\ 1, 2, 3 Laguna State Polytechnic University, Philippines
}

\begin{abstract}
Exploring new innovative and learning modalities is an urgent move of higher education as an option in this pandemic. As a result, to flexible delivery of Student Affairs and Services, as stated in CMO 8 s., 2021, Guidelines on the Implementation of Flexible Delivery of student Affairs and Services, (SAS) programs during the Covid-19 epidemic as the continuity of student services is significant to the overall development of students during this trying time. The predictors of student affairs and services (SAS) performance among higher education institutions (HEIs) were determined using a descriptivecorrelational research method. The students in the College of Teacher Education and Student Affairs and services (SAS) Unit head and staff were selected as respondents through stratified random sampling. The findings revealed that the majority of the student respondents are from HEI's in the Province of Laguna. There is a significant relationship between the students' affairs services in terms of Information and Orientation Services, Guidance and Counselling Services, Student Training, Student Organizations and Activities, Admission Services, Scholarships and Financial Assistance (SFA) and the effectiveness and efficiency of student affairs services. As recommended, the Guidance and Counselling unit must administer the student assessment tools regularly and periodically to determine the appropriate interventions necessary in the new normal. The promotion of mental health among students through different platforms may intensify more. The HEI's and SAS may consider strengthening downloadable materials and their contents as means of student orientation and information dissemination; online seminars, workshops, and conferences relative to students' program, specialization, and other relevant topics; enhance the system of recognition and accreditation, supervision, monitoring of student organizations and evaluation of its activities.
\end{abstract}

Keywords: Predictors, Effectiveness, Efficiency, Student Affairs Services

\section{INTRODUCTION}

This is an open access article under the CC-BY-NC license.

All educational institutions' goal is the continuity of learning but keeping the students safe is the crucial concern. Due to Covid-19, higher education must urgently investigate new learning modalities to ease the transition from traditional to flexible teaching and learning alternatives.

As a result, a move to flexible delivery of all student services stated in the new CMO 08, s.2021, Guidelines on the Implementation of Flexible Delivery of student Affairs and Services (SAS) is critical to the overall development of students during the epidemic.

The students in higher education are effectively satisfied when the information and knowledge they obtain are of the same high quality as what they expected a beneficial impact on their minds (Dominici and Palumbo, 2013).[4] Higher education service quality of student satisfaction, implying a higher degree of perceived higher educational service quality student contentment (Emiliani, M.L, 2005).[5] Student happiness relies on support resources, instructional quality, and learning results. (Duque and Weeks,2010)

The university's image has a significant impact on students' decision-making. University branding is a sophisticated promotion tool to engage students, pique their attention, and put the institution on the

Corresponding author salandanaflora@gmail.com; lp.buenvinida@gmail.com; marcial.bandoy@lspu.edu.ph 
International Journal of Management, Entrepreneurship, Social Science and Humanities (IJMESH), Vol. 4 (2), 99-117

Predictors of the Effectiveness and Efficiency of Student Affairs and Services (SAS) among Higher

Education Institutions (HEI's)

Flora H. Salandanan, Lerma P. Buenvinida, Marcial M. Bandoy

map. Azoury and his colleagues (2014).[1] The ability to meet student needs, development of trust in the institution's ability to provide better services to students.

In this study, Perry's theory of cognitive growth is used by student affairs services to help students learn outside of the classroom through programs, service learning, and other activities that challenge their views. The activities and programs under evaluation ensure the personality development of the students even in the flexible delivery of services. (Long, 2012)

According to Yilmaz (2017) [2], the cognitive and affective types of satisfaction among students. Student happiness is an indicator of a university's educational website's performance. Satisfaction rating is a critical component for educational institutions to optimize their profits by influencing and retaining students' behavioural attitudes and intentions.

Student affairs (SA) Services is a profession that readily submits periodic review and capability assessments to assure the quality of service provided (UNESCO, 2002). [3] The findings of this research will be beneficial to the Commission on Higher Education (CHED), particularly in the implementation of Flexible Delivery of Students Affairs and Services to different Higher Education Institutions (HEI's) in the country in time of a pandemic. The study will be useful to the administration in the university because it is a powerful tool in integrating the institution's vision, mission, goals, and objectives to the outcomes in the assessment of quality services.

The results of this research study will be advantageous for the continuous improvement of students' services in the institutions after the assessment. This study will also serve as a reference guide for future researchers in the continuity of Higher Education Institutions (HEI's) Students' Services Performance for Sustainability Assessment.

\section{Objectives of the Study}

This study aims to ensure the delivery of student services with monitoring and assessments of different activities and programs with the effectiveness and efficiency of the services provided to students.

\section{MATERIALS AND METHODS}

To establish the reliability and validity of the survey questionnaire of the study Predictors of Effectiveness and efficiency of the Students Affairs Services (SAS) among HEI's in the Province of Laguna, it was evaluated and validated by five (5) graduates of Doctor of Education major in Educational Management from different public institutions. It was evaluated and validated applying the P.M.Veroy RN, Man (2010) criteria for validation from the following features such as Clarity of and Direction of Items, Presentation and Organization of Items, Suitability of Items, Adequateness of the Content, Attainment of Purpose, Objective, Scale and Evaluation Rating.

The use of research validation provides a relation to interpret scores from the assessment of research results. The accuracy of the evaluation of the survey instrument will ensure the predictors of the effectiveness and efficiency of student affairs services under different aspects. These features will help to ensure the quality of services provided to the students to the colleges and universities. The total respondent population of the selected HEI's is 5,410 students, and 83 for unit heads/staff. A stratified random sampling method to identify the 373 student-respondents and 69-unit heads/staff. There are only 360 students in different selected institutions who answered questionnaires using online survey platforms. 
- Seek the Approval of HEI's Presidents and other officials.

-Administer Survery Questionnaires in digital form.

- Collection, Tabulation, Analysis and Interpretion of Data Gathered.

Figure1. Data Gathering Process

To determine the performance of SAS Unit in the Information and Orientation Services, Guidance and Counselling Services, Student Training, Student Organizations and Activities, Admission Services, and Scholarships and Financial Assistance (SFA) on the adopted survey questionnaires in CMO 8, series of 2021, Guidelines in Flexible Delivery of Students Affairs and Services based from CMO 9 s 2013, Area IV -Support to Students of AACCUP Survey Visit in Likert scales measures and interpreted using weighted mean scores. Weighted mean was used to determine the performance of different SAS units. Pearson Chi-Square test was also utilized to test the significant relationships between the independent and dependent variables of the study.

Independent Variable

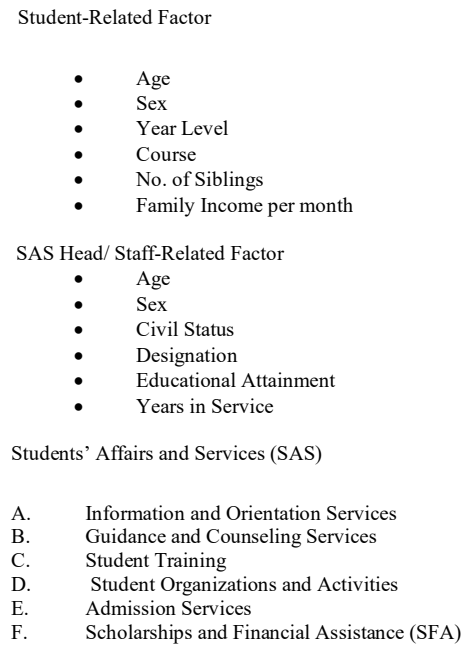

Figure 2. Research Paradigm
Dependent Variables

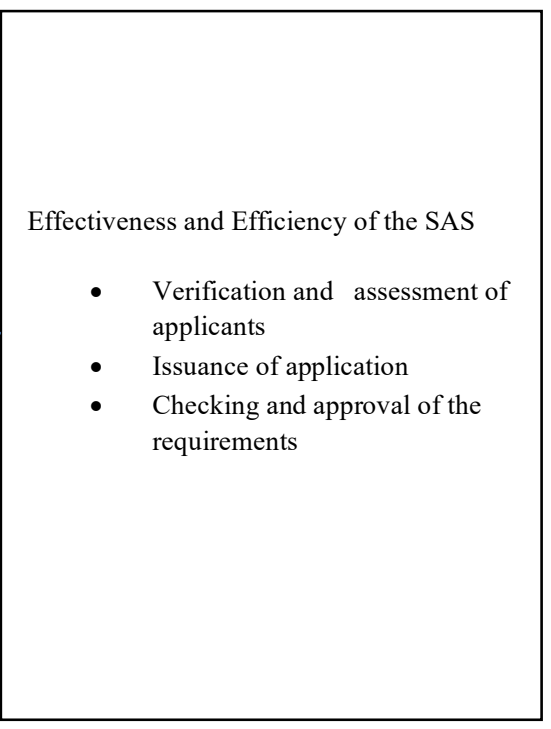

The Pearson $r$ and multiple linear regressions were used to calculate and predict the effectiveness of the SAS using indicative statements based on different features of services provided by the student affairs services. It was a tool utilized if there were two quantitative variables and a linear relationship between those variables. The multiple linear regressions equation of $\mathrm{Y}=\mathrm{a}+\mathrm{bX}$, where $\mathrm{X}$ is the explanatory variable and $\mathrm{Y}$ is the dependent variable.

This tool is for testing relationships between categorical variables. The null hypothesis of the ChiSquare test is that no relationship exists on the variables in the population; they are independent. In this study, it is the relationship of effectiveness and efficiency of SAS. The level of significance was set at .05. R Squared was used to determine the effectiveness and efficiency of the student affairs services (SAS) in the higher education institutions in the province of Laguna. It means that the relationship of variables in this research has $95 \%$ accuracy. 
International Journal of Management, Entrepreneurship, Social Science and Humanities (IJMESH), Vol. 4 (2), 99-117

Predictors of the Effectiveness and Efficiency of Student Affairs and Services (SAS) among Higher

Education Institutions (HEI's)

Flora H. Salandanan, Lerma P. Buenvinida, Marcial M. Bandoy

\section{RESULTS AND DISCUSSION}

The majority of the student-respondents (147) range from 21-23 years of age or $40.8 \%$, followed by (113) aged 24-26 years old or 31.4\%, 26.4\% (95) are 18-20-year-old, and (5) or 1.4\%,30 years old and above. The age range between 21-23 yrs old, female, third-year College, 212 of 360 respondents are Bachelor of Secondary Education, and 148 students are Bachelor of Elementary Education; several siblings are 5-6 in the family, and 232 have P5,000 to P10, 000 earnings per month of the SAS head/staff belong to the age bracket of 30-39 years old; the majority are females, 43 and 26 males, 45 were married, and 24 singles. The older students in the class usually outperform their younger

\section{Table 1. Profile of Student-Respondents}

\begin{tabular}{lll} 
Year Level & Frequency & Percent \\
\hline First Year & 74 & 20.6 \\
Second Year & 110 & 30.6 \\
Third Year & 132 & 36.7 \\
Fourth Year & 44 & 12.2 \\
Total & 360 & 100.0 \\
\hline Course & Frequency & Percent \\
\hline Bachelor of Secondary Education & 212 & 58.9 \\
Bachelor of Elementary Education & 148 & 41.1 \\
Total & 360 & 100.0 \\
\hline 1 - 2 Siblings & 33 & 9.2 \\
3 - 4 Siblings & 132 & 36.7 \\
$5-6$ Siblings & 165 & 45.8 \\
7 or more & 30 & 8.3 \\
Total & 360 & 100.0 \\
\hline Income & Frequency & Percent \\
\hline $5000-10000$ & 232 & 64.4 \\
$11000-15000$ & 84 & 23.3 \\
$16000-20000$ & 39 & 10.8 \\
over 20000 & 5 & 1.4 \\
Total & 360 & 100.0 \\
\hline
\end{tabular}

classmates in long-range cognitive and academic outcomes (Bedard and Dhuey, 2006). The majority of the students-respondents age is ideal for students' participation in different activities in the institutions.

The majority of the respondents are females, 223 or $61.9 \%$ compared to a male of 137 or $38.1 \%$ Filipino women are enrolled in high school and college at significantly higher rates than men, according to an annual report. According to the Global Gender Gap Report of the World Economic Forum (WEF, 2020).

In terms of students' year level, the majority of the student-respondents were third Year College which accounts for 132 or $36.7 \%$. The frequency and percent distribution of the respondent's siblings most numbered were $5-6,165$ or $45.8 \%$. According to Chen F. et al. (2014), the extended family structure had only a minor impact on individual well-being at earlier stages of life.

In terms of students' family income, the majority of respondents, 232 or $64.4 \%$, have P5,000 to P10,000 earnings per month. Public school education is free and typically caters to low-income children. The respondents were composed of roughly low-income families, and most of the respondents are fairly representative of urban-dwelling Filipino parents (Alampay and Jocson, 2012). 
Most of the SAS head/staff belong to the age bracket of 30-39 years old, with 26 respondents or $7.2 \%$. It is thought that a middle-aged teacher with more experience and expertise is in a better position to guide and enlighten students in the classroom (Marasigan, 2010). The great majority of SAS Head/Staff sex was 43 or $119 \%$ female respondents as compared to 26 or $7.2 \%$ male. According to the US-China Education Review (2012), more females are promoted into important and influential positions of leadership.

A great majority of respondents were 45 or $12.5 \%$ married and 24 or $6.7 \%$ single. Married employees have a significantly higher dedication to work compared to those unmarried due to their more mature role and responsibilities over their families (Deligero, 2014). [6]

Among respondents in Student Affairs Services were 38 or $10.6 \%$ from staff and 31- or 8.6 \%-Unit Head of different SAS units from OSAS, Admission, Guidance and Counselling, Scholarship and Financial Assistance, Student Organization and Activities. In terms of length of service, the majority of the respondents have rendered 1-5 years in service, which accounts for 31 respondents or $8.6 \%$ out of 69 . Employee's performance evaluation reveals strengths and weaknesses and the introduction of scientific development and achievement of the University's goals (Bazargan, 2005)

Table 2. Profile of SAS Head/Staff-Respondents

\begin{tabular}{lll}
\hline Age & Frequency & Percent \\
\hline 20-29 years old & 21 & 5.8 \\
$30-39$ years old & 26 & 7.2 \\
$40-49$ years old & 14 & 3.9 \\
$50-59$ years old & 6 & 1.7 \\
>= 60 years old & 2 & 0.6 \\
Total & 69 & 19.2 \\
\hline Sex & Frequency & Percent \\
\hline Male & 26 & 7.2 \\
Female & 43 & 11.9 \\
Total & 69 & 19.2 \\
\hline Civil Status & Frequency & Percent \\
\hline Single & 24 & 6.7 \\
Married & 45 & 12.5 \\
Total & 69 & 19.2 \\
\hline Designation & Frequency & Percent \\
\hline Unit Head & 31 & 8.6 \\
Staff & 38 & 10.6 \\
Total & 69 & 19.2 \\
\hline Education & Frequency & Percent \\
\hline College Degree & 39 & 10.8 \\
College Degree with MA/MS Units & 1 & 0.3 \\
Master's Degree & 9 & 2.5 \\
MA/MS with Doctorate Units & 9 & 2.5 \\
Doctorate Degree & 11 & 3.1 \\
Total & 69 & 19.2 \\
\hline Service & Frequency & Percent \\
\hline 1 - 5 years & 31 & 8.6 \\
6 - 10 years & 25 & 6.9 \\
11 - 15 years & 9 & 2.5 \\
16 - 20 years & 2 & 0.6 \\
over 20 years & 2 & 0.6 \\
Total & 69 & 19.2 \\
\hline & &
\end{tabular}


Table 3. The information and orientation services

\begin{tabular}{|c|c|c|c|c|c|c|c|c|c|}
\hline \multirow[b]{2}{*}{$\begin{array}{l}\text { Information and Orientation Services } \\
\text { Indicative Statements }\end{array}$} & \multicolumn{3}{|c|}{ Students } & \multicolumn{3}{|c|}{ Employees } & \multicolumn{3}{|c|}{ Combine } \\
\hline & 寻 & के & 总 & 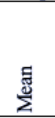 & के & 递 & 芯 & के & 量 \\
\hline $\begin{array}{l}\text { 1. The school system offers an orientation program } \\
\text { for new students, returnees, and transferees and their } \\
\text { families to share college/university vision, mission, } \\
\text { policies, } \\
\text { procedures, and expectations. }\end{array}$ & 3.86 & 0.83 & $\begin{array}{l}\text { Very } \\
\text { Satisfactory }\end{array}$ & 4.48 & 0.55 & Very Satisfactory & 3.96 & 0.82 & Very Satisfactory \\
\hline $\begin{array}{l}\text { 2. A wide dissemination of all information, concern, } \\
\text { and activities to students and in the } \\
\text { college/university community in different ways are } \\
\text { given. }\end{array}$ & 4.17 & 0.65 & $\begin{array}{l}\text { Very } \\
\text { Satisfactory }\end{array}$ & 4.59 & 0.55 & Excellent & 4.24 & 0.65 & Very Satisfactory \\
\hline $\begin{array}{l}\text { 3. Printed or digital information and orientation } \\
\text { materials (brochures, handouts, } \\
\text { orientation and learning packet, manual, etc.) to } \\
\text { students are readily available. }\end{array}$ & 3.96 & 0.63 & $\begin{array}{l}\text { Very } \\
\text { Satisfactory }\end{array}$ & 4.33 & 0.61 & Very Satisfactory & 4.02 & 0.64 & Very Satisfactory \\
\hline $\begin{array}{l}\text { 4. Different organizations indicating their } \\
\text { relationship with other units are introduced to } \\
\text { college/university-wide. }\end{array}$ & 4.04 & 0.60 & $\begin{array}{l}\text { Very } \\
\text { Satisfactory }\end{array}$ & 4.45 & 0.53 & Very Satisfactory & 4.11 & 0.61 & Very Satisfactory \\
\hline $\begin{array}{l}\text { 5. The accomplishments of the SAS are disseminated } \\
\text { to students, faculty, staff, and administrators. }\end{array}$ & 4.16 & 0.74 & $\begin{array}{l}\text { Very } \\
\text { Satisfactory }\end{array}$ & 4.38 & 0.59 & Very Satisfactory & 4.19 & 0.72 & Very Satisfactory \\
\hline Composite Mean & 4.04 & 0.51 & $\begin{array}{l}\text { Very } \\
\text { Satisfactory }\end{array}$ & 4.45 & 0.32 & Very Satisfactory & 4.10 & 0.51 & Very Satisfactory \\
\hline
\end{tabular}

Table 3 depicts that the mean performance of the Information and Orientation Services as evaluated by the respondents was ranging from 3.96 to 4.24 from indicative statements of the following: The school system offers an orientation program for new students, returnees and transferees and their families to share college/university vision, mission, policies, procedures, and expectations.

Printed or digital information and orientation materials (brochures, handouts, orientation and learning packet, manual, etc.) to students are readily available with mean scores of 4.02. Different organizations indicating their relationship with other units are introduced college/university-wide with mean scores of 4.11 .

The accomplishments of the SAS were disseminated to students, faculty, staff, and administrators with mean scores of 4.19. And lastly, wide dissemination of all information, concern, and activities to students and in the college/university community in different ways are given with mean scores of 4.24 . The overall mean assessed by the respondents of students and SAS Head/Staff in Information and Orientation Services was 4.10, interpreted as Very Satisfactory.

The orientation service is provided to students who are newcomers to the school and those who are starting a new semester or course. It is for students to learn about school courses, rules, regulations, the various facilities provided by the school, and everything else about the school. 
International Journal of Management, Entrepreneurship, Social Science and Humanities (IJMESH), Vol. 4 (2), 99-117

Predictors of the Effectiveness and Efficiency of Student Affairs and Services (SAS) among Higher

Education Institutions (HEI's)

Flora H. Salandanan, Lerma P. Buenvinida, Marcial M. Bandoy

Table 4. The Guidance and Counselling services

世

\begin{tabular}{|c|c|c|c|c|c|c|c|c|c|}
\hline \multirow{2}{*}{$\begin{array}{l}\text { Guidance and Counselling Services } \\
\text { Indicative Statements }\end{array}$} & \multicolumn{3}{|c|}{ Students } & \multicolumn{3}{|c|}{ Employees } & \multicolumn{3}{|c|}{ Combine } \\
\hline & $\sum^{\mathbb{\Xi}}=$ & क & 志总导 & $\sum^{\mathbb{E}}=$ & के & 䓌递 & $\stackrel{\Xi}{\Sigma}_{\Sigma}=$ & के & 䓌总总 = \\
\hline $\begin{array}{l}\text { 1. The Guidance and Counselling } \\
\text { unit conducted remote } \\
\text { psychological first aid, } \\
\text { teleconferencing, mental health } \\
\text { campaigns through mobile or } \\
\text { landline. }\end{array}$ & 3.94 & 0.63 & $\begin{array}{l}\text { Very } \\
\text { Satisfactory }\end{array}$ & 4.14 & 0.75 & $\begin{array}{l}\text { Very } \\
\text { Satisfactory }\end{array}$ & 3.97 & 0.65 & $\begin{array}{l}\text { Very } \\
\text { Satisfactory }\end{array}$ \\
\hline $\begin{array}{l}\text { 2. The Guidance and Counselling } \\
\text { Unit has partnerships with } \\
\text { organizations where the students } \\
\text { are in or living. }\end{array}$ & 3.76 & 0.85 & $\begin{array}{l}\text { Very } \\
\text { Satisfactory }\end{array}$ & 4.00 & 1.08 & $\begin{array}{l}\text { Very } \\
\text { Satisfactory }\end{array}$ & 3.80 & 0.89 & $\begin{array}{l}\text { Very } \\
\text { Satisfactory }\end{array}$ \\
\hline $\begin{array}{l}\text { 3. The unit conducted different } \\
\text { intervention programs and } \\
\text { services to promote and enhance } \\
\text { student welfare and development. }\end{array}$ & 3.77 & 1.00 & $\begin{array}{l}\text { Very } \\
\text { Satisfactory }\end{array}$ & 4.04 & 1.08 & $\begin{array}{l}\text { Very } \\
\text { Satisfactory }\end{array}$ & 3.81 & 1.02 & $\begin{array}{l}\text { Very } \\
\text { Satisfactory }\end{array}$ \\
\hline $\begin{array}{l}\text { 4. There is a webinar series for } \\
\text { mental health and wellness for } \\
\text { students. }\end{array}$ & 3.81 & 0.72 & $\begin{array}{l}\text { Very } \\
\text { Satisfactory }\end{array}$ & 4.09 & 0.81 & $\begin{array}{l}\text { Very } \\
\text { Satisfactory }\end{array}$ & 3.85 & 0.75 & $\begin{array}{l}\text { Very } \\
\text { Satisfactory }\end{array}$ \\
\hline $\begin{array}{l}\text { 5. Gender-sensitive individual and } \\
\text { group counseling is provided } \\
\text { through online platforms. }\end{array}$ & 3.85 & 0.80 & $\begin{array}{l}\text { Very } \\
\text { Satisfactory }\end{array}$ & 4.25 & 0.77 & $\begin{array}{l}\text { Very } \\
\text { Satisfactory }\end{array}$ & 3.91 & 0.81 & $\begin{array}{l}\text { Very } \\
\text { Satisfactory }\end{array}$ \\
\hline Composite Mean & 3.82 & 0.42 & $\begin{array}{l}\text { Very } \\
\text { Satisfactory }\end{array}$ & 4.10 & 0.56 & $\begin{array}{l}\text { Very } \\
\text { Satisfactory }\end{array}$ & 3.87 & 0.46 & $\begin{array}{l}\text { Very } \\
\text { Satisfactory }\end{array}$ \\
\hline
\end{tabular}

Table 4 shows that the mean performance of the guidance and counseling services ranged from 3.80 to 3.97. The overall mean assessed by the combined respondents of students and SAS Head/Staff in Guidance and Counselling was 3.87, interpreted as Very Satisfactory. Guidance and counseling services assist individuals in knowing and understanding themselves, accepting their superior and limited characteristics and developing themselves, trusting themselves, developing effective interpersonal relationships, and becoming personally and socially balanced and harmonious individuals (Yesilyaprak, 2001). 
International Journal of Management, Entrepreneurship, Social Science and Humanities (IJMESH), Vol. 4 (2), 99-117

Predictors of the Effectiveness and Efficiency of Student Affairs and Services (SAS) among Higher

Education Institutions (HEI's)

Flora H. Salandanan, Lerma P. Buenvinida, Marcial M. Bandoy

Table 5. The mean performance of student training services

\begin{tabular}{|c|c|c|c|c|c|c|c|c|c|}
\hline \multirow[b]{3}{*}{ Indicative Statements } & \multicolumn{6}{|c|}{ Student Training } & \multirow{2}{*}{\multicolumn{3}{|c|}{ Combine }} \\
\hline & \multicolumn{3}{|c|}{ Students } & \multicolumn{3}{|c|}{ Employees } & & & \\
\hline & Mean & SD & 总。号 & $\sum_{\Sigma}^{\Xi}$ & SD & $\begin{array}{l}\text { Inter } \\
\text { preta } \\
\text { tion }\end{array}$ & $\sum_{\Sigma}^{\Xi}$ & SD & 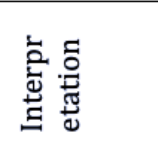 \\
\hline $\begin{array}{l}\text { 1. Provide students a list of } \\
\text { online webinars-workshops } \\
\text { and conferences. }\end{array}$ & 4.15 & 0.74 & $\begin{array}{l}\text { Very } \\
\text { Satisfact } \\
\text { ory }\end{array}$ & 4.13 & 0.95 & $\begin{array}{l}\text { Very } \\
\text { Satisfac } \\
\text { tory }\end{array}$ & 4.15 & 0.77 & $\begin{array}{l}\text { Very } \\
\text { Satisfactor } \\
\mathrm{y}\end{array}$ \\
\hline $\begin{array}{l}\text { 2. The institution provides } \\
\text { leadership training to } \\
\text { students. }\end{array}$ & 3.86 & 0.62 & $\begin{array}{l}\text { Very } \\
\text { Satisfact } \\
\text { ory }\end{array}$ & 4.57 & 0.60 & $\begin{array}{l}\text { Excellen } \\
\mathrm{t}\end{array}$ & 3.97 & 0.67 & $\begin{array}{l}\text { Very } \\
\text { Satisfactor } \\
\mathrm{y}\end{array}$ \\
\hline $\begin{array}{l}\text { 3. Give skills training and } \\
\text { development programs. }\end{array}$ & 3.66 & 0.71 & $\begin{array}{l}\text { Very } \\
\text { Satisfact } \\
\text { ory }\end{array}$ & 4.04 & 0.75 & $\begin{array}{l}\text { Very } \\
\text { Satisfac } \\
\text { tory }\end{array}$ & 3.72 & 0.73 & $\begin{array}{l}\text { Very } \\
\text { Satisfactor } \\
\mathrm{y}\end{array}$ \\
\hline $\begin{array}{l}\text { 4. Send printed materials on } \\
\text { leadership training modules } \\
\text { to student leaders. }\end{array}$ & 4.08 & 0.89 & $\begin{array}{l}\text { Very } \\
\text { Satisfact } \\
\text { ory }\end{array}$ & 3.93 & 0.77 & $\begin{array}{l}\text { Very } \\
\text { Satisfac } \\
\text { tory }\end{array}$ & 4.06 & 0.87 & $\begin{array}{l}\text { Very } \\
\text { Satisfactor } \\
\mathrm{y}\end{array}$ \\
\hline $\begin{array}{l}\text { 5. Provides opportunities for } \\
\text { promotion and appreciation } \\
\text { of culture and arts through } \\
\text { varied activities. }\end{array}$ & 3.56 & 0.88 & $\begin{array}{l}\text { Very } \\
\text { Satisfact } \\
\text { ory }\end{array}$ & 4.19 & 1.04 & $\begin{array}{l}\text { Very } \\
\text { Satisfac } \\
\text { tory }\end{array}$ & 3.66 & 0.94 & $\begin{array}{l}\text { Very } \\
\text { Satisfactor } \\
\text { y }\end{array}$ \\
\hline Composite Mean & 3.86 & 0.46 & $\begin{array}{l}\text { Very } \\
\text { Satisfact } \\
\text { ory }\end{array}$ & 4.17 & 0.62 & $\begin{array}{l}\text { Very } \\
\text { Satisfac } \\
\text { tory }\end{array}$ & 3.91 & 0.50 & $\begin{array}{l}\text { Very } \\
\text { Satisfactor } \\
\mathrm{y}\end{array}$ \\
\hline
\end{tabular}

Table 5 shows aspects of student training that range from 3.66 to 4.15 . The overall mean assessed by the combined students and SAS Head/Staff in student training was 3.91, interpreted as Very Satisfactory.

The students learn as a result of their involvement in student groups aids in evaluating and justifying the efficacy of programs and services provided. It helps to demonstrate the value of a specific program or service provided by student organizations (McCluskey-Titus,2003).

Students with similar mindsets together to engage in career activities, student organizations should as a practical and beneficial means of learning are recognized.

For students, this is a valuable source of personal growth because it offers them valuable leadership, management, and expertise (Hall, 2012). Student organization involvement had a positive impact on teamwork, determination, and citizenship. Student clubs, according to Hall (2012), "often expedite theoretical and societal participation while pursuing a variety of activities."

Working alone does not provide students with as much experience, or understanding of a discipline as participating in student organizations does (Andrews, 2007).

In their study, Dungan and Komives (2007) found that any level of involvement in studies. Students with similar mindsets together to engage in important career activities, student organizations should be recognized as a practical and beneficial means of learning. For them, this is a valuable source of personal growth. 
International Journal of Management, Entrepreneurship, Social Science and Humanities (IJMESH), Vol. 4 (2), 99-117

Predictors of the Effectiveness and Efficiency of Student Affairs and Services (SAS) among Higher

Education Institutions (HEI's)

Flora H. Salandanan, Lerma P. Buenvinida, Marcial M. Bandoy

Table 6. The mean performance of student organizations and activities

\begin{tabular}{|c|c|c|c|c|c|c|c|c|c|}
\hline \multirow[b]{2}{*}{$\begin{array}{l}\text { Student Organizations } \\
\text { and Activities } \\
\text { Indicative Statements }\end{array}$} & \multicolumn{3}{|c|}{ Students } & \multicolumn{3}{|c|}{ Employees } & \multicolumn{3}{|c|}{ Combine } \\
\hline & ฆี & ณิ & 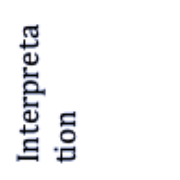 & 忍 & คิ & 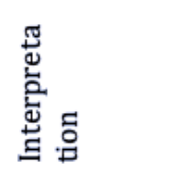 & 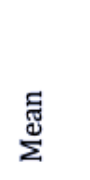 & ڤิ & 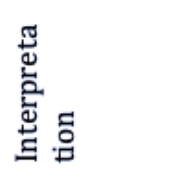 \\
\hline $\begin{array}{l}\text { 1. Allow submission of } \\
\text { recognition/accreditation } \\
\text { documents online or at } \\
\text { drop-off points in the } \\
\text { college/university. }\end{array}$ & 4.44 & 0.63 & $\begin{array}{l}\text { Very } \\
\text { Satisfactory }\end{array}$ & 4.41 & 0.60 & $\begin{array}{l}\text { Very } \\
\text { Satisfactory }\end{array}$ & 4.44 & 0.62 & $\begin{array}{l}\text { Very } \\
\text { Satisfactory }\end{array}$ \\
\hline $\begin{array}{l}\text { 2. Grant other forms of } \\
\text { support to accredited } \\
\text { student organizations in } \\
\text { the college/university. }\end{array}$ & 4.41 & 0.67 & $\begin{array}{l}\text { Very } \\
\text { Satisfactory }\end{array}$ & 4.68 & 0.55 & Excellent & 4.45 & 0.66 & $\begin{array}{l}\text { Very } \\
\text { Satisfactory }\end{array}$ \\
\hline $\begin{array}{l}\text { 3. The requirements and } \\
\text { procedures for } \\
\text { recognition/accreditation } \\
\text { of student organizations } \\
\text { are widely disseminated } \\
\text { offline and online. }\end{array}$ & 4.02 & 0.66 & $\begin{array}{l}\text { Very } \\
\text { Satisfactory }\end{array}$ & 4.57 & 0.58 & Excellent & 4.11 & 0.68 & $\begin{array}{l}\text { Very } \\
\text { Satisfactory }\end{array}$ \\
\hline $\begin{array}{l}\text { 4. Give online platforms } \\
\text { or virtual meeting rooms } \\
\text { to student organizations } \\
\text { for their student } \\
\text { activities. }\end{array}$ & 3.54 & 0.66 & $\begin{array}{l}\text { Very } \\
\text { Satisfactory }\end{array}$ & 4.38 & 0.54 & $\begin{array}{l}\text { Very } \\
\text { Satisfactory }\end{array}$ & 3.68 & 0.71 & $\begin{array}{l}\text { Very } \\
\text { Satisfactory }\end{array}$ \\
\hline $\begin{array}{l}\text { 5. Strongly emphasize } \\
\text { observance of proper } \\
\text { discipline even in online } \\
\text { classes }\end{array}$ & 3.82 & 0.85 & $\begin{array}{l}\text { Very } \\
\text { Satisfactory }\end{array}$ & 4.17 & 0.45 & $\begin{array}{l}\text { Very } \\
\text { Satisfactory }\end{array}$ & 3.88 & 0.81 & $\begin{array}{l}\text { Very } \\
\text { Satisfactory }\end{array}$ \\
\hline Composite Mean & 4.05 & 0.33 & $\begin{array}{l}\text { Very } \\
\text { Satisfactory }\end{array}$ & 4.44 & 0.36 & $\begin{array}{l}\text { Very } \\
\text { Satisfactory }\end{array}$ & 4.11 & 0.36 & $\begin{array}{l}\text { Very } \\
\text { Satisfactory }\end{array}$ \\
\hline
\end{tabular}

Table 6 depicts the Student Organization and Activities that had to be evaluated, and it was assessed ranging from 3.68 to 4.45 to different concerns such as The overall evaluation by the respondents of students and SAS Head/Staff in student organizations and activities was 3.87 interpreted as Very Satisfactory.

Participation in student organizations and clubs is a significant instrument for personal development in students at colleges and universities (McCluskey-Titus, 2003).

Employing different intervention programs, tie-ups with affiliate organizations and continuous guidance in a flexible digital way will ensure the best services to students. Assessment of the college's student affairs services program's implementation and effectiveness is an attempt to identify the strengths and weaknesses of the various services offered by the Student Development Services Office with the end goal of designing a Comprehensive Development Plan for Student Affairs Services Program that will respond to the college's vision of "Quality and Excellence" (Ibarrientos, 2015). 
International Journal of Management, Entrepreneurship, Social Science and Humanities (IJMESH), Vol. 4 (2), 99-117

Predictors of the Effectiveness and Efficiency of Student Affairs and Services (SAS) among Higher

Education Institutions (HEI's)

Flora H. Salandanan, Lerma P. Buenvinida, Marcial M. Bandoy

Table 7. The mean performance of Admission Services

\begin{tabular}{|c|c|c|c|c|c|c|c|c|c|}
\hline \multirow[b]{2}{*}{$\begin{array}{l}\text { Admission Services } \\
\text { Indicative Statements }\end{array}$} & \multicolumn{3}{|c|}{ Students } & \multicolumn{3}{|c|}{ Employees } & \multicolumn{3}{|c|}{ Combine } \\
\hline & 灵 & 皇 & 을 열 & 丞 & 号 & 흘열 & ฏี & 兵 & 흘열 \\
\hline $\begin{array}{l}\text { 1. Provide online } \\
\text { recruitment, selection, } \\
\text { admission services. }\end{array}$ & 4.57 & 0.53 & Excellent & 4.46 & 0.60 & Excellent & 4.55 & 0.55 & Excellent \\
\hline $\begin{array}{l}\text { 2. There is a wide and } \\
\text { well|dissemination of } \\
\text { admission services in } \\
\text { different ways. (Digital } \\
\text { and printed). }\end{array}$ & 4.44 & 0.53 & $\begin{array}{l}\text { Very } \\
\text { Satisfactory }\end{array}$ & 4.39 & 0.66 & $\begin{array}{l}\text { Very } \\
\text { Satisfactory }\end{array}$ & 4.44 & 0.56 & $\begin{array}{l}\text { Very } \\
\text { Satisfactory }\end{array}$ \\
\hline $\begin{array}{l}\text { 3. Policies and } \\
\text { procedures on } \\
\text { selection, admission, } \\
\text { and retention of } \\
\text { students are } \\
\text { implemented and } \\
\text { disseminated to } \\
\text { students via } \\
\text { Google/zoom meet } \\
\text { and other online\& } \\
\text { offline ways. }\end{array}$ & 4.30 & 0.60 & $\begin{array}{l}\text { Very } \\
\text { Satisfactory }\end{array}$ & 4.30 & 0.67 & $\begin{array}{l}\text { Very } \\
\text { Satisfactory }\end{array}$ & 4.30 & 0.61 & $\begin{array}{l}\text { Very } \\
\text { Satisfactory }\end{array}$ \\
\hline $\begin{array}{l}\text { 4. Admission records } \\
\text { are filed in soft and } \\
\text { hard copies to make } \\
\text { them more available to } \\
\text { concerned parties. }\end{array}$ & 4.39 & 0.56 & $\begin{array}{l}\text { Very } \\
\text { Satisfactory }\end{array}$ & 4.45 & 0.60 & $\begin{array}{l}\text { Very } \\
\text { Satisfactory }\end{array}$ & 4.40 & 0.56 & $\begin{array}{l}\text { Very } \\
\text { Satisfactory }\end{array}$ \\
\hline $\begin{array}{l}\text { 5. There is a } \\
\text { consultation and } \\
\text { approval of retention } \\
\text { policies by higher } \\
\text { authorities(Academic } \\
\text { Council/Board of } \\
\text { Trustees/Regents). }\end{array}$ & 4.24 & 0.51 & $\begin{array}{l}\text { Very } \\
\text { Satisfactory }\end{array}$ & 4.41 & 0.60 & $\begin{array}{l}\text { Very } \\
\text { Satisfactory }\end{array}$ & 4.27 & 0.53 & $\begin{array}{l}\text { Very } \\
\text { Satisfactory }\end{array}$ \\
\hline Composite Mean & 4.39 & 0.38 & $\begin{array}{l}\text { Very } \\
\text { Satisfactory }\end{array}$ & 4.40 & 0.43 & $\begin{array}{l}\text { Very } \\
\text { Satisfactory }\end{array}$ & 4.39 & 0.39 & $\begin{array}{l}\text { Very } \\
\text { Satisfactory }\end{array}$ \\
\hline
\end{tabular}

Table 7 portrays that the mean performance of the admission services as evaluated by the respondents was ranging from 4.27 to 4.55 . The overall mean performance measured from the responders was 4.39, interpreted as Very Satisfactory.

According to Orr (2017), an equitable admissions system prioritizes students' chances of success, regardless of their socioeconomic status. As a result, admissions processes play a critical role in mediating and resolving inequities for students.

Furthermore, an effective admissions system ensures that students' interests and capabilities are matched to the appropriate higher education program. It also enables modifications in study patterns to match society's and the labor market's new and continuously changing demands (Orr, 2017). 
International Journal of Management, Entrepreneurship, Social Science and Humanities (IJMESH), Vol. 4 (2), 99-117

Predictors of the Effectiveness and Efficiency of Student Affairs and Services (SAS) among Higher

Education Institutions (HEI's)

Flora H. Salandanan, Lerma P. Buenvinida, Marcial M. Bandoy

Table 8. The mean performance of Scholarship and Financial Assistance

Mean Performance of Student Affairs and Services

\begin{tabular}{l|c|c|c}
\hline Services & Mean & SD & Interpretation \\
\hline Information and Orientation & 4.10 & 0.51 & Very Satisfactory \\
\hline Guidance and Counseling & 3.87 & 0.46 & Very Satisfactory \\
\hline Student Training & 3.91 & 0.50 & Very Satisfactory \\
\hline Student Organizations and Activities & 4.11 & 0.36 & Very Satisfactory \\
\hline Admission & 4.39 & 0.39 & Very Satisfactory \\
\hline Scholarship and Financial Assistance & 4.41 & 0.28 & Very Satisfactory \\
\hline Overall Mean & 4.13 & 0.20 & Very Satisfactory \\
\hline
\end{tabular}

1.0-1.49: Needs Improvement; 1.5-2.49: Fair; 2.5-3.49: Satisfactory; 3.5-4.49: Very Satisfactory; 4.5-5.0: Excellent

The table shows the mean performance of Scholarship and Financial Assistance as assessed by the respondents ranging from 4.28 to 4.45 . The overall means performance measured by SAS Head/staff and students' respondents was 4.41 , interpreted as Very Satisfactory. 
International Journal of Management, Entrepreneurship, Social Science and Humanities (IJMESH), Vol. 4 (2), 99-117

Predictors of the Effectiveness and Efficiency of Student Affairs and Services (SAS) among Higher Education Institutions (HEI's)

Flora H. Salandanan, Lerma P. Buenvinida, Marcial M. Bandoy

Table 9. The Mean Performance of Student Affairs and Services

\begin{tabular}{|c|c|c|c|c|c|c|c|c|c|}
\hline \multirow{2}{*}{$\begin{array}{l}\text { Scholarship and Financial } \\
\text { Assistance }\end{array}$} & \multicolumn{2}{|c|}{ Students } & \multicolumn{4}{|c|}{ Employees } & \multicolumn{3}{|c|}{ Combine } \\
\hline & ฐ̃ & के & $\begin{array}{l}\text { Interpretati } \\
\text { on }\end{array}$ & స్ & คิ & $\begin{array}{l}\text { Interpretati } \\
\text { on }\end{array}$ & ญี & คิ & $\begin{array}{l}\text { Interpretati } \\
\text { on }\end{array}$ \\
\hline $\begin{array}{l}\text { 1. Access to different } \\
\text { scholarships and financial } \\
\text { assistance are available to } \\
\text { students via Facebook, Gmail, } \\
\text { and other digital forms and } \\
\text { allows limited consultation in } \\
\text { the college/university. }\end{array}$ & 4.45 & 0.59 & $\begin{array}{l}\text { Very } \\
\text { Satisfactory }\end{array}$ & 4.36 & $\begin{array}{l}0.6 \\
6\end{array}$ & \begin{tabular}{|l|} 
Very \\
Satisfactory
\end{tabular} & 4.43 & 0.60 & $\begin{array}{l}\text { Very } \\
\text { Satisfactory }\end{array}$ \\
\hline $\begin{array}{l}\text { 2. There is an online } \\
\text { application and submission of } \\
\text { documents for Scholarship } \\
\text { and Assistance applicants. }\end{array}$ & 4.48 & 0.52 & $\begin{array}{l}\text { Very } \\
\text { Satisfactory }\end{array}$ & 4.35 & $\begin{array}{l}0.6 \\
6\end{array}$ & \begin{tabular}{|l|} 
Very \\
Satisfactory
\end{tabular} & 4.45 & 0.55 & $\begin{array}{l}\text { Very } \\
\text { Satisfactory }\end{array}$ \\
\hline $\begin{array}{l}\text { 3. Updates, Guidelines on } \\
\text { scholarship, and financial } \\
\text { assistance are posted in } \\
\text { different digital forms. }\end{array}$ & 4.43 & 0.52 & $\begin{array}{l}\text { Very } \\
\text { Satisfactory }\end{array}$ & 4.42 & $\begin{array}{l}0.6 \\
5\end{array}$ & \begin{tabular}{|l|} 
Very \\
Satisfactory
\end{tabular} & 4.43 & 0.54 & $\begin{array}{l}\text { Very } \\
\text { Satisfactory }\end{array}$ \\
\hline $\begin{array}{l}\text { 4. There are financial } \\
\text { assistance programs designed } \\
\text { for a merit scholarship. }\end{array}$ & 4.24 & 0.43 & $\begin{array}{l}\text { Very } \\
\text { Satisfactory }\end{array}$ & 4.49 & $\begin{array}{l}0.5 \\
3\end{array}$ & \begin{tabular}{|l|} 
Very \\
Satisfactory
\end{tabular} & 4.28 & 0.45 & $\begin{array}{l}\text { Very } \\
\text { Satisfactory }\end{array}$ \\
\hline $\begin{array}{l}\text { 5. There is continuous } \\
\text { monitoring and assessment of } \\
\text { grantees/scholars in their } \\
\text { academic status. }\end{array}$ & 4.41 & 0.49 & $\begin{array}{l}\text { Very } \\
\text { Satisfactory }\end{array}$ & 4.57 & $\begin{array}{l}0.5 \\
0\end{array}$ & Excellent & 4.44 & 0.50 & $\begin{array}{l}\text { Very } \\
\text { Satisfactory }\end{array}$ \\
\hline Composite Mean & 4.40 & 0.27 & $\begin{array}{l}\text { Very } \\
\text { Satisfactory }\end{array}$ & 4.44 & $\begin{array}{l}0.3 \\
3\end{array}$ & \begin{tabular}{|l|} 
Very \\
Satisfactory
\end{tabular} & 4.41 & 0.28 & \begin{tabular}{|l|} 
Very \\
Satisfactory
\end{tabular} \\
\hline
\end{tabular}

Legend:1.0-1.49: Needs Improvement;1.5-2.49: Fair;2.5-3.49: Satisfactory;3.5-4.49: Very Satisfactory;4.5-5.0: Excellent

Table 9 shows that the mean performance of the student affairs and services as assessed by the respondents was ranging from 3.87 to 4.41 . The overall mean assessed by the respondents of students and SAS Head/Staff was 4.13, interpreted as Very Satisfactory.

Student services play a vital role in preparing students for active participation in society. They contribute to enhanced learning opportunities and community involvement by organizing or promoting internships, experiential units, or short-term experiences that are integrated into the curricula in collaboration with instructors and non-governmental groups (UNESCO, 2002). 
Table 10. The Mean Performance on Efficiency

\begin{tabular}{l|c|c|c}
\hline \multicolumn{4}{c}{ Mean Performance on Efficiency } \\
\hline \multicolumn{1}{c|}{ Efficiency } & Mean & SD & Interpretation \\
\hline Verification and Assessment & 4.43 & 0.32 & Very Satisfactory \\
\hline Issuance and Application & 4.37 & 0.38 & Very Satisfactory \\
\hline Checking and Approval & 4.35 & 0.40 & Very Satisfactory \\
\hline Overall Mean & 4.38 & 0.26 & Very Satisfactory \\
\hline
\end{tabular}

1.0-1.49: Needs Improvement; 1.5-2.49: Fair; 2.5-3.49: Satisfactory; 3.5-4.49: Very Satisfactory; 4.5-5.0: Excellent

Table 10 shows that the mean performance of the student affairs and services in terms of efficiency as assessed by the respondents was ranging from 4.35 to 4.43 from Verification and Assessment, Issuance and Application and Checking of Approval from different SAS units that provide the following criteria: promptness of the service, courtesy of the provider and quality of the service. Overall mean performance on efficiency by the respondents of students and SAS Head/Staff was 4.38, interpreted as Very Satisfactory.

Based on college impact theories, student affairs professionals should purposefully provide opportunities and resources for students (Pascarella \& Terenzini, 2005).

Student Affairs and Services must continuously and purposefully approach the end aim of providing worthy students with someone to be proud of their desire to achieve their life goals (Ibarrientos, 2015).

The effectiveness of Student Affairs divisions is responsible for meeting the developmental requirements of the student population (Coomes \& Gerda, 2016) and for educating the entire student population (Martin \& McGee, 2014).

Student affairs professionals are responsible for expanding the purpose of a college education by supplementing classroom instruction. Student Affairs professionals strive to improve student learning by providing experiences with a holistic development lens in mind (Martin \& McGee, 2014).

The survey discovered that SAS programs were present and applied to a "great level" in selected HEIs in Bulacan. According to the research of policy study of SAS among higher education institutions in Bulacan. (Mercado, Hilario, and Nuqui, 2015).

Another survey, similar to the one given by Galvez (2018), evaluated the satisfaction rating of student affairs and services at the same university. The majority of students were delighted with the quality of services of the student services unit.

Table 11. Student's Profile and the Efficiency of SAS Student's Profile VS Efficiency Chi-Square Test 
International Journal of Management, Entrepreneurship, Social Science and Humanities (IJMESH), Vol. 4 (2), 99-117 Predictors of the Effectiveness and Efficiency of Student Affairs and Services (SAS) among Higher Education Institutions (HEI's)

Flora H. Salandanan, Lerma P. Buenvinida, Marcial M. Bandoy

\begin{tabular}{|c|c|c|c|}
\hline Profile & Effectiveness and Efficiency & X2 (Chi-Square) & Df (Degrees of freedom) \\
\hline \multirow{4}{*}{ Age } & Verification and Assessment & $82.34 * *$ & 9 \\
\hline & Issuance and Application & $52.97 * *$ & 9 \\
\hline & Checking and Approval & $67.26^{* *}$ & 9 \\
\hline & Composite Mean & $220.71^{* *}$ & 24 \\
\hline \multirow{4}{*}{ Sex } & Verification and Assessment & 2.52 & 3 \\
\hline & Issuance and Application & $56.32 * *$ & 3 \\
\hline & Checking and Approval & $45.56^{* *}$ & 3 \\
\hline & Composite Mean & $89.14^{* *}$ & 8 \\
\hline \multirow{4}{*}{ Year Level } & Verification and Assessment & $93.65 * *$ & 9 \\
\hline & Issuance and Application & $121.91^{* *}$ & 9 \\
\hline & Checking and Approval & $89.15^{* *}$ & 9 \\
\hline & Composite Mean & $215.82 * *$ & 24 \\
\hline \multirow{4}{*}{ Course } & Verification and Assessment & $86.38 * *$ & 3 \\
\hline & Issuance and Application & $50.89 * *$ & 3 \\
\hline & Checking and Approval & $12.37 * *$ & 3 \\
\hline & Composite Mean & $154.22 * *$ & 8 \\
\hline \multirow{4}{*}{ Siblings } & Verification and Assessment & $69.15^{* *}$ & 9 \\
\hline & Issuance and Application & $64.14^{* *}$ & 9 \\
\hline & Checking and Approval & $36.95 * *$ & 9 \\
\hline & Composite Mean & $111.53 * *$ & 24 \\
\hline \multirow{2}{*}{ Family Income } & Verification and Assessment & $39.86^{* *}$ & 9 \\
\hline & Issuance and Application & $25.19 * *$ & 9 \\
\hline
\end{tabular}


International Journal of Management, Entrepreneurship, Social Science and Humanities (IJMESH), Vol. 4 (2), 99-117

Predictors of the Effectiveness and Efficiency of Student Affairs and Services (SAS) among Higher

Education Institutions (HEI's)

Flora H. Salandanan, Lerma P. Buenvinida, Marcial M. Bandoy

\begin{tabular}{l|l|c|c}
\hline & Checking and Approval & $54.25^{* *}$ & 9 \\
\cline { 2 - 4 } & Composite Mean & $85.25^{* *}$ & 24 \\
\hline
\end{tabular}

** - Significant @ p-value <.01

Pearson Chi-Square test was calculated to compare the relationship between the student's profile efficiency of student affairs and services. A significant relationship between profile efficiency was found in all except only between the profile sex and verification and assessment (X2(3)=252, p-value>.05).

The Chi-Square statistic used testing relationships between categorical data of respondents profiles found in independent variables such as age, sex, year level, course siblings, and family to measure the frequency and percentage and compare to other variables to test their significant relationship.

Table 12. Profile of unit heads/ staff and the SAS efficiency

Employee's Profile VS Efficiency Chi-Square Test

\begin{tabular}{|c|c|c|c|}
\hline Profile & Efficiency & X2(Chi-Square) & Df (Degrees of freedom) \\
\hline \multirow{4}{*}{ Age } & Verification and Assessment & 10.32 & 12 \\
\hline & Issuance and Application & 8.40 & 12 \\
\hline & Checking and Approval & $22.54^{*}$ & 12 \\
\hline & Composite Mean & 30.79 & 32 \\
\hline \multirow{4}{*}{ Sex } & Verification and Assessment & 0.89 & 3 \\
\hline & Issuance and Application & 3.04 & 3 \\
\hline & Checking and Approval & 3.93 & 3 \\
\hline & Composite Mean & 6.04 & 8 \\
\hline \multirow{4}{*}{ Civil Status } & Verification and Assessment & 3.50 & 3 \\
\hline & Issuance and Application & 3.93 & 3 \\
\hline & Checking and Approval & 1.74 & 3 \\
\hline & Composite Mean & 12.42 & 8 \\
\hline Designation & Verification and Assessment & 1.03 & 3 \\
\hline
\end{tabular}


International Journal of Management, Entrepreneurship, Social Science and Humanities (IJMESH), Vol. 4 (2), 99-117

Predictors of the Effectiveness and Efficiency of Student Affairs and Services (SAS) among Higher

Education Institutions (HEI's)

Flora H. Salandanan, Lerma P. Buenvinida, Marcial M. Bandoy

\begin{tabular}{|c|c|c|c|}
\hline & Issuance and Application & 0.14 & 3 \\
\hline & Checking and Approval & 2.39 & 3 \\
\hline & Composite Mean & 6.46 & 8 \\
\hline \multirow{4}{*}{ Education } & Verification and Assessment & 5.32 & 12 \\
\hline & Issuance and Application & 16.45 & 12 \\
\hline & Checking and Approval & 12.58 & 12 \\
\hline & Composite Mean & 33.62 & 32 \\
\hline \multirow{4}{*}{ Years in Service } & Verification and Assessment & 12.28 & 12 \\
\hline & Issuance and Application & 12.00 & 12 \\
\hline & Checking and Approval & $27.80 * *$ & 12 \\
\hline & Composite Mean & 35.80 & 32 \\
\hline
\end{tabular}

** - Significant @ p-value <.01;* - Significant @ p-value <.05

Table 10 shows that the Pearson Chi-Square test was calculated to compare the relationship between the SAS Head/Staff profile and efficiency of student affairs and services. A significant relationship between a profile in terms of age efficiency in terms of checking and approval $(\mathrm{X} 2(12)=22.54$, pvalue $<.05)$ and profile in terms of years in service efficiency of student affairs and services in terms of checking and approval $(\mathrm{X} 2(12)=27.80$, p-value $<.01)$.

Table 13. Pearson Correlation - Services and Effectiveness and Efficiency

\begin{tabular}{l|l|c|c|c|c}
\hline \multicolumn{2}{l|}{ Student Affairs and Services } & $\begin{array}{c}\text { Verification } \\
\text { and } \\
\text { Assessment }\end{array}$ & $\begin{array}{c}\text { Issuance and } \\
\text { Application }\end{array}$ & $\begin{array}{c}\text { Checking } \\
\text { and } \\
\text { Approval }\end{array}$ & Overall \\
\hline Information and Orientation & R-value & $.325^{* *}$ & $.133^{* *}$ & $-.192^{* *}$ & $.102^{*}$ \\
\hline Guidance and Counseling & R-value & 0.092 & 0.072 & $.135^{* *}$ & $.144^{* *}$ \\
\hline Student Training & R-value & $-.123^{*}$ & $.237^{* *}$ & $.099^{*}$ & $.118^{*}$ \\
\hline $\begin{array}{l}\text { Student Organizations and } \\
\text { Activities }\end{array}$ & R-value & 0.021 & $.225^{* *}$ & $.133^{* *}$ & $.189^{* *}$ \\
\hline Admission & R-value & $.187^{* *}$ & $.145^{* *}$ & $.195^{* *}$ & $.251^{* *}$ \\
\hline
\end{tabular}


International Journal of Management, Entrepreneurship, Social Science and Humanities (IJMESH), Vol. 4 (2), 99-117

Predictors of the Effectiveness and Efficiency of Student Affairs and Services (SAS) among Higher

Education Institutions (HEI's)

Flora H. Salandanan, Lerma P. Buenvinida, Marcial M. Bandoy

\begin{tabular}{l|l|l|l|l|l}
\hline $\begin{array}{l}\text { Scholarship and Financial } \\
\text { Assistance }\end{array}$ & R-value & $.309^{* *}$ & $.550^{* *}$ & $.139^{* *}$ & $.473^{* *}$ \\
\hline Overall & R-value & $.266^{* *}$ & $.434^{* *}$ & $.151^{* *}$ & $.404^{* *}$ \\
\hline
\end{tabular}

** - Correlation is significant at $\mathrm{p}$-value $<.01 ;^{*}$ - Correlation is significant at $\mathrm{p}$-value $<.05$

Table 13 shows, information, and orientation were significantly related to effectiveness and efficiency of student affairs and services in terms of verification and assessment (R-value $=.325, \mathrm{p}$-value<.01), issuance and application (R-value $=.133$, p-value $<.01$, checking and approval (R-value=-.192, pvalue $<.01$ ) and overall mean of effectiveness and efficiency [R-value=.102, $p$-value<.05); guidance and counseling were significantly related to effectiveness and efficiency of student affairs and services in terms of checking and approval (R-value $=.135$, p-value $<.01$ ) and overall mean of effectiveness and efficiency (R-value $=.144$, p-value $<.01$ )

This Pearson's correlation is a measure of association between two continuous variables. Pearson's correlation in this table measures the relationship of SAS unit effectiveness and efficiency of their services using Citizen Charter Rating in terms of verification and assessment, Issuance and Application, Checking and approval to evaluate the performance.

\section{Table 14. Effectiveness and Efficiency of SAS}

\begin{tabular}{|c|c|c|c|c|c|}
\hline \multicolumn{6}{|l|}{ Result of Multiple Linear Regression } \\
\hline Predictors & Beta & t-value & R Square & $\begin{array}{c}\text { Df } \\
\text { (degrees of } \\
\text { freedom) }\end{array}$ & $\mathrm{F}$ \\
\hline (Constant) & 1.72 & 7.71 & \multirow{4}{*}{0.27} & \multirow{2}{*}{3} & \multirow{4}{*}{$52.75^{* *}$} \\
\hline Scholarship and Financial Assistance & 0.43 & 11.45 & & & \\
\hline Student Organizations and Activities & 0.14 & 4.73 & & \multirow{2}{*}{425} & \\
\hline Information and Orientation & 0.05 & 2.34 & & & \\
\hline
\end{tabular}

Table 12 depicts a multiple linear regression was calculated to predict the effectiveness of student affairs and services based on information and orientation, guidance and counseling, student training, student organizations and activities, admission, and scholarship and financial assistance.

A significant regression was found out $(F(3,425)=52.75$, p-value $<.01)$, with an $R$ square of 0.27 . Participants' predicted effectiveness of student affairs and services are equal to $1.72+0.43$ (scholarship and financial assistance) +0.14 (student organizations and activities +0.05 (information and orientation), where scholarship and financial assistance, student organizations and activities, and information and orientation between 1 and 5 .

An increase of 1.72 units for effectiveness and efficiency of student affairs and services for every 0.43 scholarships and financial assistance, 0.14 student organizations and activities, and 0.05 information and orientation. Scholarship and financial assistance, student organizations and activities, and 
International Journal of Management, Entrepreneurship, Social Science and Humanities (IJMESH), Vol. 4 (2), 99-117

Predictors of the Effectiveness and Efficiency of Student Affairs and Services (SAS) among Higher

Education Institutions (HEI's)

Flora H. Salandanan, Lerma P. Buenvinida, Marcial M. Bandoy

information and orientation were predictors of the effectiveness and efficiency of student affairs and services.

Respondents predicted effectiveness and efficiency of student affairs and services are equal to scholarship and financial assistance, student organizations and activities, information, and orientation. Thus, other student services affairs units may consider enhancing their plan of activities and programs services. This study revealed that there are things to be considered to meet the standard quality in the flexible delivery of services. Lastly, according to UNESCO (2002), Student Affairs (SA) is a profession that automatically undergoes periodic evaluation and capability assessment to ensure the quality of service delivered to students.

\section{CONCLUSION AND RECOMMENDATION}

There is no significant relationship between the profile of students and the effectiveness and efficiency of student affairs services. There is a relationship between the students and the effectiveness and efficiency of student affairs services.

There is no significant relationship between the profile of unit heads, staff profile, the effectiveness, and efficiency of student affairs services was partly upheld. There is a relationship between the unit heads and staff profile and the effectiveness and efficiency of student affairs services.

There is no significant relationship between the students' affairs services Information and Orientation Services, Guidance and Counseling Services, Student Training, Student Organizations and Activities, Admission Services, Scholarships and Financial Assistance (SFA) effectiveness and efficiency of student affairs services.

The hypothesis has partly upheld the relationship between the students' affairs services Information and Orientation Services, Guidance and Counseling Services, Student Training, Student Organizations and Activities, Admission Services, Scholarships and Financial Assistance (SFA), effectiveness and efficiency of student affairs services.

Based on the summary of findings and conclusions:

- The Guidance and Counselling unit may administer the student assessment tools regularly and periodically to determine the appropriate interventions for the students.

- The student affairs and services and the registered guidance counselors may conduct promotional campaigns of mental health among students through mobile or landline telecommunication and limited face-to-face conferences following the minimum health standards prescribed by the government.

- The HEI's and SAS may consider strengthening downloadable materials and their contents as means of student orientation and information dissemination.

- The SAS with different units and colleges in HEI's may conduct an increasing number of online seminars, workshops, and conferences relative to the program, specialization, and other relevant topics for the student welfare. 
- The SAS, colleges, and the Unit of Student Organizations and activities may enhance the system of recognition and accreditation, supervision and monitoring of student organizations, and evaluation of its activities. It is also recommended for further comprehensive study in the delivery of services and programs.

\section{REFERENCES}

[1] Azoury, Nehme et al. (2014).University image and its relationship to student satisfaction- case of the Middle Eastern private business schools, Research Gate,DOI:10.1016/j.ism.2014.07.001.

[2] Yilmaz, Ercan et al. (2017). Variables Affecting Student Motivation Based on Academic Publications Journal of Education and Practice www.iiste.org ISSN 2222-1735 (Paper)ISSN 2222-288X (Online)

[3] UIE.(2002).Annual report 2002: UNESCO Institute for Education, uil.unesco.org/journalinternational-review-of-education

[4] Dominici and Palumbo, (2013), The Drivers of Customer Satisfaction in the Hospitality Industry. Applying the Kano's Model to Sicilian Hotels, Int. J. Leisure and Tourism Marketing, Vol. 3, No. 3, 2013

[5] Emiliani, M.L. (2005) Using Kaizen to Improve Graduate Business School Degree Programs. Quality Assurance in Education, 13, 37-52.

[6] Joseph Cezar L. Deligero \& Jake M. Laguador, 2014. "Work Engagement among Employees and Its Relationship with Work Unitsâ€ ${ }^{\mathrm{TM}}$ Performance of a Higher Education Institution," International Journal of Management Sciences, Research Academy of Social Sciences, vol. 3(12), pages 909-917. 